\title{
Research on the Mode and Method of Fund Management in Colleges and Universities
}

\author{
Yuanyuan Tian ${ }^{1, a}$ \\ 'Zaozhuang University, Zaozhuang 277160, China \\ amoralist@126.com
}

\section{Keywords: Funds management; Expense account; Colleges}

\begin{abstract}
The development of universities in the market economy is severely restricted by capital. In university financial management, how to strengthen capital management, streamline the reimbursement process, optimization of investment gold efficiency, the use of limited funds for sustainable development are the keys to finding a balance between stability and development in colleges and universities. This paper takes the current situation of fund management model and expenditure of some universities in China as an example, compared with foreign universities funds management mode and methods, pointing out the problems and drawbacks of its increasing prominence and putting forward the rationalization proposal and solution of the college fund through further system optimization and process optimization.
\end{abstract}

\section{Introduction}

Under the environment of socialist market economy, the current capital situation the development of universities confront is that although the scale of enrollment is expanding and the government investment is increasing year by year, they still have a large gap with university infrastructure, teaching and scientific research and sustainable development. The financial management of colleges and universities, especially the capital management, is the prerequisite and guarantee of the development of colleges and universities. It is related to the development and stability of a series of work such as education and teaching, science and technology research, infrastructure construction and logistics support.

The use and management of funds in colleges and universities is mainly composed of the pre-budget of funds, during-the-event accounting, control and ex post supervision, analysis and other aspects. Through the investigation of the current situation of the use of funds in a university, the author analyzes the problems that have become increasingly prominent, compares them with the mode and method of capital management of foreign universities, and puts forward the improvement plan for the capital management of colleges and universities. Respectively from the capital management model, system construction of process control, the computer network and modern office means, start from establishing information construction of financial management information system, optimize the reimbursement process, strengthen the management of the funds to achieve the maximum efficiency of the use of funds.

\section{An Analysis of the Current Situation of Fund Management in Foreign Universities.}

American Colleges and Universities belong to the Government of Special Purpose. The taxation the government can obtain tax revenue as a source of government funds through, and provide financial resources to colleges and universities through the development of budget, which constitutes a part of the funding of colleges and universities with social investment funds.

Since the 1980s, the governance system of colleges and universities has gradually adopted the system of board of laymen, and has implemented the president responsibility system under the leadership of the board of directors. The board of directors of the American University formulates policies and manages the internal affairs of the university through the establishment of a standing 
committee. There into, the Executive Committee, Implementer Financial Planning Committee is responsible for submitting the budget and the allocation of funds for specific arrangements, and regularly assess the use of funds, internal and external debt situation [1,2]. Capital management implements decentralized management model. The board of directors develops this year and long-term fund management plan, and the president of the school is responsible for the implementation of the policy. This management model is an important guarantee for the vigorous development of higher education in the United States, Japan and other Western developed countries, in the second half of the twentieth century. To a certain extent, the separation of decision-making and implementation is conducive to not only that the board of directors, without the balance of the school development and other external environmental factors, develops various financial policies, which is beneficial to the school's long-term development planning, but also that various subordinate colleges implement the funds management policy forwardly, creatively and independently in the funds Management activities. There are a greater freedom running a school and financial autonomy in the implementation of the financial policy, which greatly improves the efficiency of capital management.

There must be three following conditions in the capital management decentralization mode: First, funds should be strictly managed by the school central unified management, and unified financial scheduling should be implemented. "Centralized management is the most economical management." Secondly, equip advanced and scientific computer system of the central management. This system makes a detailed record, settlement and management of the entire school's various subordinate school-running entity's financial management department's the financial income and expenditure, budget formulation and implementation and others activities, and supervise its strict operation in accordance with the board of directors' planning and arrangement. Third, develop tightly regulated capital management policies, and strictly monitor the implementation of policies.

German Universities Rely mainly on Federal Government Funding and Corporate Investment. State government funding is mainly responsible for the management cost of colleges and universities, equipment investment, half of spending of fundamental construction (the other half is paid by the federal government subsidies), and so on. In addition, the German university research funding can also apply to the central government for additional funding; business investment accounts for about $40 \%$ of the total school revenue.

From this, we can see that the German government investment in higher education funds are more. Through the capital investment and subsidies of the federal government and the state government, the higher education funds of the German is sufficient to pay the general administrative expenses of general expenses of school. Funds from the "third party" enterprises, which is known as the "third category of funds", are raised and fought by its teachers through their own research projects, enterprises-signed technology transfer or research and development contracts, so this funds are entirely and freely controlled by the teacher himself. In addition, colleges and universities not only accept the constraints of national government and legal, but also the flexibility of running a school and a certain autonomy for the control of educational resources.

\section{An Analysis of the Current Situation of Fund Management in a domestic university.}

Funds Shortage. Financial capital investment is steadily increasing year by year. Annual income mainly includes nearly 200 million of funds the financial allocating within the budget, extra-budgetary funds collected by tuition fees and housing disposal income and others. With the increasing enrollment in colleges and universities, there is still a large gap between infrastructure investment, logistical support and funds needed by long-term development. The gap of funds can only rely on financing of financial institutions.

Funds Adopt Model Combined Decentralized Management with Macro-Control. The current allocation of financial funds in a university adopts the model, which mainly relies on decentralized management and is supplemented by integrated management. [3,4]. That is, the majority of the funds are allocated to various secondary institutions and the competent department of the special funds according to the use of funds in previous years at the beginning of the year 
when making budget. The secondary college or party and government officials of competent department of the special funds is responsible for the use and approval of funds. Only a small amount of funds is used for college basic maintenance and development needs.

Low Efficiency. The approval processes of multi-level duplication and the complex reimbursement processes are all made by the manual operation, which has a serious impact on the efficiency of capital use. In our country, the reimbursement of expenses refers to the behavior that all the original vouchers, which is related to the economic business acquired or produced in the daily economic activities by stuffs of the organs or enterprises and institutions, is deposited for record at the financial department and handed over to the financial department for settlement and verification. Although a university's financial accounting work has achieved the accounting computerization, it is in essence the closed system only for the financial sector financial staff , and just alternative tools of the original functions such as manual preparation of vouchers, manual billing, manual checkout and review functions .It cannot cover all aspects of the reimbursement process, financial software or network system cannot complete functions such as budget reporting, budget control, leadership approval, real-time staff reimbursement and other functions in real time. A university's reimbursement process is as follows:

Economic business generates, acquire and produce original documents. The reimbursement stuffs of the various departments obtain or produce, generate the legitimate original certificate of economic work or aggregate original vouchers, that is, travel claims reimbursement, wages (school allowance, bonus) payment table, funds reimbursement summary, cash receipts (faculties fill in by hand).

Budget declaration. On the basis of the phased features of the financial allocation, in order to distinguish priorities of funds of use, co-ordinate and make most of the funds of all stages, College Finance Department adds a step before the financial reimbursement, in which before using funds the reimbursement personnel of various departments fills in "a college budget implementation approval form" and makes a application for the use of the funds.(Since the contents of the approval form are similar to the content of invoice summary , the staff need to fill information repeatedly).Department head who uses funds, department head in charge of special funds shall sign and stamp (the first approval of leaders) on the budget implementation approval form, and then submit it to the Finance Department after summarized by various secondary colleges. The following table is a Implementation and approval form of college budget:

Form1 Implementation and approval form of college budget

Application units (Stamp):

Application

time:

\begin{tabular}{|c|c|c|c|c|c|c|c|}
\hline \multirow[b]{2}{*}{$\begin{array}{l}\text { Detailed use of } \\
\text { fund }\end{array}$} & Fund sources & & ad sum & & Serv & ice time & \\
\hline & \multicolumn{7}{|c|}{$\begin{array}{l}\text { Signature of the head of the democratic financial team } \\
\text { Reported units(Stamp) }\end{array}$} \\
\hline $\begin{array}{c}\text { Signature of head } \\
\text { of competent } \\
\text { department }\end{array}$ & \multicolumn{7}{|c|}{ Signature of head of competent department } \\
\hline $\begin{array}{l}\text { Argument } \\
\text { opinion }\end{array}$ & \multicolumn{7}{|c|}{ Signature of head of leading group of argument } \\
\hline Funding advice & \multicolumn{4}{|c|}{ Planning and Finance Division(Stamp) } & $\begin{array}{l}\text { nature c } \\
\text { Year }\end{array}$ & $\begin{array}{l}\text { f head } \\
\text { Month }\end{array}$ & Date \\
\hline
\end{tabular}

Note:

(1) This form is original, after the argument signs opinions, should be return to the declaration unit.(2)

Departmental all-round responsibility funds and special funds should be separately declared.All funds are in duplicate.(3)For the declaration of special funds of the competent department, the head of the competent department should sign it. 
Budget Approval. The democratic financial management group the College set up makes approvals of applications of funds use summarized by the whole colleges.

The application form after approval shall be stamped with the signature of head of the democratic financial management team and the responsible person in charge of the finance department (the leader's second approval). Members of the democratic financial management team are composed of the discipline inspection committee, finance department, state-owned assets department, science and technology department and other departments responsible person.

Invoice Approval. After the approval of the application for funds (i.e., the budget approval form), the responsible person in charge of the department or special fund administration department shall examine and approve the original voucher (the leader's third approval).

Accounting Review. Accounting personnel mainly review two items, one is whether the use of funding applications is approved, the other is the authenticity, the legitimacy, integrity of the original certificate, whether approval of the signature and t) he expenditure of the project is reasonable and so on.

Finance Office Makes a Payment and account Processing. Payment is transferred via bank POS machine. The financial staff shall make a voucher according to the original vouchers that have been reviewed and paid, make an accounting, production of financial statements and so on according to the accounting law requirements.

\section{Problems and Disadvantages of Fund Management in a University}

The following aspects of the contradiction has become increasingly prominent and deepened in a university financial management:

A university funds are mainly from the financial allocation, and the school itself cannot raise and attract foreign funds. In addition to maintaining daily teaching, research, logistics and other work. Funds to increase the school capital construction and carry out career development is extremely limited. There is a serious shortage of funds. It is one of the urgent problems to speed up the cash flow and improve the utilization of funds.

In scattered management model of financial funds, the majority of funds are allocated to the secondary colleges or special funds departments, and make financial rights relatively decentralized. It is not easy to concentrate funds to do big things, not conducive to the mobilization of funds at any time and complementary redundancy, and also easy to cause duplication of expenses for certain projects or funds. In addition, the responsible persons of the secondary college or the functional departments have a certain degree of control of the use of the department or the special funds, which is easy to cause corruption.

Operation mode of manual, the complicated funding process and layers of approval system often have following drawbacks. First, the reimbursement need fill a variety of documents by hand. It has large amount of information and more repetitive work, involves many approvals of department, occupies a lot of work time of staff. Second, a large number of sporadic, anytime and anywhere, manual, repeated works of the signing disrupt the work plans of the leadership and increase the time and cycle of reimbursement and funds, so that the cash flow and use efficiency greatly reduced.

\section{Solutions}

In order to improve the use efficiency of funds, accelerate the optimization of capital efficiency, and establish and improve the financial management system of colleges and universities, institutionalizing and standardizing the aspects of capital co-ordination, financial control and reimbursement process can improve the efficiency of capital optimization.

Co-ordination and Control of Funds. First of all, scientific research and personnel advantages of universities' own should be used, 
by the increasing cooperation with local and enterprises, to transfer patent technology, provide paid services, carry out different ways of joint of school and government, joint of enterprise and school, joint among schools, and attract capital investment, equipment investment or various forms of resources on the university's investment, in order to maximize the increase in funding sources [5,6]. Second, the funds of university and other resources should be concentrated to a large financial system, the allocation of funds are changed from the original way, which distributes by the department and the special objects, to the way, which distributes only by special allocation and set aside a certain amount of mobility funds. The university should establish the unified leadership of principals, centralized co-ordination and management model for resource (especially the capital), in order to facilitate the limited funds for basic and important projects, and concentrate resources and do big thing. This method is very conducive to the complementary lack of funds, and avoid duplicated expense of multiple departments and multiple projects, and also shun the corruption.

Financial Management Control. It mainly includes the control of budget management, the control of the approval system and the control of accounting and supervision of the major responsible person in charge of the funds.

Strict implement the budget at the beginning of the year, make a real-time control of budget execution progress, strictly grasp the budget execution results. The phenomenon of ultra-budget should be avoided. The approval system should be not only legitimate, compliance, but also simplified, scientific. Only in this way the time, which the leadership wastes in the working hours and energy of the approval, can be saved for management and decision-making. What's more, it can improve the efficiency of capital use. The school funds should be distributed in the special funds, such as research funding, teaching funds, internship funds, laboratory funds. Financial resources and rights should be focused on the special funding departments. So it should establish a strict audit supervision system, which supervises the competent departments to make good use of funds.

Optimize the Reimbursement Process. The budget approval link should be added in the traditional funds reimbursement process. Although it can make a certain control on the use, deployment and the remaining of funds of the different stages, but greatly increases the cost of reimbursement on the whole: Faculties repeatedly fill in a large number of information, the staff and workers require various levels of the approval of funding, various responsible persons make repeated re-approval, various department submits materials to the finance department, the finance department summarize material cost generated from the total material and so on. At the same time, it extends funding reimbursement time and reduces the efficiency of the use of funds. Therefore, the role of the budget approval link is far from being able to compensate for the reduced efficiency and should be eliminated.

In addition, the author of this article designs a set of safe, practical and efficient financial management software, which covers budget declaration of the staff, reimbursement documents fill, and approval of various departments and responsible person in charge of funds[7]. On the basis of today's university campus network platform, openness, information sharing and high-speed of network are used to meet the user's different financial activities of reimbursement, accounting, budget control, receivables management, information query, decision-making and other needs. This project has also been funded by a university. The completed financial reimbursement system that is put into use reflects the advantages which is easy to operate, query, manage, controlled., greatly enhances a university financial management, optimize the reimbursement process, and improve the efficiency of the use of funds.

\section{Conclusion}

By the analysis of the current situation of capital management and the expenditure of a university, this paper compares the mode and methods of capital management of foreign universities, and concludes that the system optimization and process optimization can improve the efficiency of university funds in deed. The problems existing in the process of fund management and fund expenditure are not only a single case, but also exist commonness. Therefore, the research on this 
problem has some guiding significance to other fund management work with the same scale and similar financial status.

\section{References}

[1] T.Mavruk, E.Carlsson: Social Science Electronic Publishing, Vol.5(2015)No.1,P33.

[2] C.G.Zhang: University Logistrics Research, (2013)No3, P61 (In Chinese).

[3] H.W.Wang:CFO Comments, (2017)No3, P50 (In Chinese).

[4] S.S.Yu: Economist, (2017)No6, P198 (In Chinese).

[5] Y.Liang, S.D.Gan: J. Sichuan Normal University (Social Sciences Edution), Vol.41 (2017)No2, P79 (In Chinese).

[6] Y.F.Jiang, Y.F.Wu, B.Wang: J.Nanjing Institute of Industry Tehnology, (2017)No.1, P31 (In Chinese).

[7] Y.Y.Tian: International conference on ICESAME (Zhengzhou, China, April 29-30, 2017), Vol.123, P378. 